\title{
Conditioning Factors in the Integration of Technology in the Teaching of Portuguese Non- Native Language: A Post-COVID 19 Reflection for the Current Training of Teachers
}

\author{
Joana Carvalho, Inmaculada Sánchez Casado and Sixto Cubo Delgado \\ Extremadura University (UEx), Spain \\ https://orcid.org/0000-0002-0663-013X \\ https://orcid.org/0000-0001-5165-8003 \\ https://orcid.org/0000-0001-8802-9980
}

\begin{abstract}
This presentation is the result of a mixed research and part of a PHD investigation, aimed to understand whether in the process of integrating technology in teaching Portuguese as a Non-Native Language (PNNL), external conditions such as age, time and teacher experience justify the low use of digital resources in language teaching, even though we live in the digital era currently modulated by the COVID-19 pandemic. It was also sought to understand whether training (initial and continuous) endows the teacher with skills to integrate technology in teaching. Data were obtained from 101 PNNL teachers with experience in Portugal and abroad. The results showed that training has no influence on the use of digital resources in education; age and experience influence low utilization due to lack of confidence and teacher's attitudes; and, regarding time, it was noticed that these digital resources could be facilitating elements in time management. It was concluded that we should focus heavily on CALL training for PNNL teaching, in particular due to the standardization that occurred in distance learning, caused by COVID-19, in order to provide teachers with digital literacy, thus enhancing greater time management, greater confidence and a more adjusted attitude to socio-constructivism.
\end{abstract}

Keywords: teaching second language; resources in language teaching; digital resources; digital literacy; post COVID-19

\section{Introduction}

Besides Portugal and the other eight Portuguese Language (PL) countries (Nadais, 2018), Portuguese is spoken by millions of people in diasporas and as a foreign language (Flores, 2013; Grayley, 2014). 
With European, Brazilian and African variants, PL brings together linguistic particularities such as sociolects, dialects or regionalisms, as well as standards that influence its use, communication and teaching (Branco, et al., n.d.). From all this, the concept Portuguese as a Non-Native Language (PNNL) emerges, which comprises a conceptual problem given its scope, concentration of different types of acquisition, learning and mastery of the language (Carvalho, 2013; Flores, 2013). Furthermore, PNNL integrates Portuguese as a Second Language (PSL), Portuguese as a Foreign Language (PFL) and Portuguese as a Heritage Language (PHL).

PNNL is a broad concept and it is characterized by its diversity and heterogeneity. It highly affects its Didactics (Carvalho, 2013). Simultaneously, multiculturalism and multilingualism imply the adoption of specific teaching approaches, far from traditional pedagogical practices.

The multidisciplinary of the knowledge of PNNL teachers presumes a strong commitment to training, a profound scientific, pedagogical-didactic, and technological updating. However, there is a huge rift in this field owing to the lack of didactic material. Its elaboration, as Castro (2015) mentioned, is generally based on the experiences of the authors, to the detriment of an effective integration of the recent results of research developed in the area of Second Language Acquisition (SLA) (Castro, 2017); and very focused on discrete forms and frequent use low-level practice activities as listen and repeat, dialogue repetition, matching and filling in the blanks (Tomlinson, 2012), that is, in the presentation-practice-production approach (Tomlinson, 2012).

The knowledge of PNNL teachers is not expected to be only linguistic. It must be global where digital competence is integrated as well. It is expected, therefore, that teacher training will be programmed according to the demands of modern, socio-constructivist teaching, working with diverse knowledges, preparing teachers for the pedagogical use of technology, working with various teaching methodologies, considering the multiplicity of contexts and the heterogeneity of the target audience, developing materials considering numerous application scenarios (e.g., Massive Open Online Courses - MOOC, Virtual Environments VLE, Flipped Learning). The teacher must have a variety of knowledge and the training of (future) teachers should play a particularly important role in this regard. In the process of teaching teachers, that begin to be proven by successive generations, that is Gen Y, Z and Millennials (Goh \& Abdul-Wahab, 2020), one must bear in mind "that the current teaching staff may lack the pedagogy to teach in this 'digitized' world and to be competent to lead future teachers into the new era of technology driven environment" (Goh \& Abdul-Wahab, 2020, p. 163).

Research in language education has been set aside for the benefit of learning, although for close to two decades this scenario has begun to subvert itself (Van den Branden, 2016). This task is not naturally easy and requires a (re)construction of teaching training practices (Missel, 2018; Moreira \& Monteiro, 2015; Wünsch, 2013). Language teachers need technology-level preparation, and 
to put into practice such knowledge in teaching contexts or in similar scenarios; contextualized tasks that simulate real teaching situations; support at the level of training, and even institutional; and opportunities for collaborative and reflective hands-on practices (Aşık \& Gonen, 2019).

Training practices (initial and continuous) of teachers in the use of technologies, in Portugal, is still very attached to traditional practices and models of teacher preparation in general (Costa, 2013). In the international context the scenario is not substantially different (Goh and Abdul-Wahab, 2020).

With the accelerated and global advance in technology, teachers ought to develop digital competence, in order to obtain access, analyze and synthesize, reflect and validate and, finally, transmit knowledge, using technologies in general and ICT in particular (Bastos, 2014). However, introducing technologies in teaching implies bearing in mind two major groups of constraints: internal (e.g., teachers; instructors; beliefs; views on technology; views on teaching, learning and knowledge) (Costa, 2012); and external (e.g., lack of time; inadequate preparation; lack of knowledge; lack of will, lack of resources; age; inadequate use; experience) (Kessler \& Hubbard, 2017; Mahdi \& Al-Dera, 2013; Sjöberg \& Lilja, 2019; Uzunboylu \& Tuncay, 2010).

Technology, among the multiple beneficial contributions to language teaching and learning, allows interaction and collaboration between PNNL teachers; sharing, reflection and analysis of methodologies adopted; development of digital materials and other resources, depending on the needs and contexts of teaching. It is precisely at this point that the question that led this research arises: what training do PNNL teachers receive to use digital resources in the teaching process?

Therefore, this investigation aimed to find out which variables would limit the adoption of technologies in education. Throughout the analysis of this objective, a relationship was also established with the consequences of the COVID-19 pandemic. Since external constraints are perhaps more determinant than internal constraints (Costa, 2012), we wanted to understand (specific objectives) whether the variables age, time and experience of the teacher would be at the origin of the obstacle of the use of technological resources in the teaching of PNNL. At the same time, we tried to understand whether the training (initial and continuous) that the teacher received was, per se, a justification element for not integrating technologies in language teaching. Focusing on these objectives, we have outlined the following hypotheses:

H1. The use of digital resources does not increase due to continuous training. $\mathrm{H} 2$. The use of digital resources decreases depending on age, experience, and time.

$\mathrm{H} 2.1$. The use of digital resources decreases depending on age.

H.2.2. The use of digital resources decreases depending on experience.

H.2.3. The use of digital resources decreases depending on time. 


\section{Literature Review}

The Portuguese Language (PL) is the national and official language of nine countries - Portugal, Brazil, East Timor, Angola, Mozambique, Sao Tome and Principe, Cape Verde, Guinea Bissau and Macau-, and holds a privileged position in the world, both in cross-border education and in Portugal's increasingly growing demand for a diverse audience (ERASMUS students; students from African-speaking countries Portuguese Official - PALOP; and East Timor, among others) (Bizarro, Flores \& Moreira, 2013).

Since the great voyages of discovery around the world, PL has been exposed to different contact situations, as well as different learning contexts. With three variants (European, Brazilian and African) (Leiria, 2001), PL brings together linguistic particularities (e.g., sociolects, dialects, regionalisms), as well as standards that influence their use, communication and teaching (Branco, et al., n.d.), in addition to being spoken by a wide spectrum of speakers (e.g., children of Portuguese emigrants; immigrants living in Portugal; non-native speakers; individuals who learn it as a language subject in school). For all this, the concept Portuguese as a Non-Native Language (PNNL), comprises a conceptual problem (Grosso, n.d.), given its scope; and concentrates different types of acquisition, learning and mastery of the language (Carvalho, 2013; Flores, 2013). There are three types of PNNL: Portuguese as a Second Language (PSL) (J. Ferreira, 2014); Portuguese as a Foreign Language (PFL) (Osório \& Meyer, 2008); Portuguese as a Heritage Language (PHL) (Barbosa \& Flores, 2011; Flores \& Melo-Pfeifer, 2014).

The concept PNNL vastly contemplates a whole diversity and heterogeneity about the context in which its teaching can occur, complexing the task of its Didactics (Carvalho, 2013). On the other hand, there is another factor relating to those who learn it. This is the heterogeneity of students who, per se, are deserving of a specific teaching approach. Multiculturalism and multilingualism in the classroom lead teachers to distance themselves from traditional pedagogical practices (Ndiaye, 2010). For all this, teaching PNNL (PSL/PFL/PHL) implies specific skills (Bolívar \& Ruano, 2013), which go beyond linguistics. Amateurism, the range of good intentions, the idea that anyone can teach their language, which by the way has guided successive generations of teachers, are incompatible with the demands of modern teaching. The multidisciplinary of the knowledge of the PNNL teacher presupposes a strong bet on scientific, pedagogical-didactic and, of course, technological training and updating. However, in practice, there is still a huge rift in this field, and in many cases there is a significant lack of pedagogical preparation for many teachers, who are also faced with a huge lack of adequate, diversified and certified teaching material (Tavares, 2008), despite the tremendous and valuable work that has been done in this regard (Silva \& Marçalo, 2015; Castro, 2017; Melo-Pfeifer \& Araújo e Sá, 2013).

In the case of PSL material aimed at adult audiences, Castro (2015) mentioned that there are several gaps that roughly translate into the trend of drawing up materials that are not addressed to a specific audience or learning context; and, on the other hand, the fact that they focus on communicative skills, to the 
detriment of fundamental general competences, such as learning competence or intercultural awareness, contrary to what is the case in equivalent manuals aimed at teaching other foreign languages.

Although, nationally and internationally, there are materials of some quality intended for language learning, it is a fact that they tend to be based mainly on the intuition and experience of the authors, and are still poorly guided by current learning principles, concluding that the preparation of materials could benefit much more from the investigations around the Acquisition of Second Language (ASL) (Tomlinson, 2012). Indeed, teacher training courses have a very important role to play in promoting knowledge about the L2 acquisition process and the principles underlying various current pedagogical approaches, so that the action of teachers and their combination for the development of teaching materials can be more informed and sustained. Training should, among many other functions, include a critical observation of existing materials, which corresponds, at least, to introducing them to procedures close to those of research, at the methodological level (Leiria, 2001). Technologies then emerge as an added value, to the extent that they enhance a renewal of teaching (Xambre \& Morais, 2014).

The materials for learning a language are, as Tomlinson (2012) suggested, "anything that can be used to facilitate the learning of a language, including coursebooks, videos, graded readers, flash cards, games, websites, and mobile phone interactions, though, inevitably, much of the literature focuses on printed materials" (p. 144). In fact, the difference between paper materials and digital materials lies in how content and methodology are communicated, and what really matters is the impact of certain materials on learners and the quality of their learning (Masuhara \& Tomlinson, 2018).

Digital materials are defined as materials that are made available digitally. In theory, can be used anywhere, anytime, with all their multifunctionalities and interconnectivities (Reinders \& White, 2010). Digital materials can be foreign language teaching materials, and therefore CALL (Computer Assisted Language Learning), available on websites, computer software, courseware and online courses, web sources of language experience (e.g., Google, YouTube, Facebook) and ICT applications which can be made use of both, to deliver materials and to facilitate interaction (e.g., mobile phones) (Tomlinson, 2012). But regarding delivery, in which software and applications (e.g., apps) change rapidly (e.g., Web 2.0 for Web 3.0, and Web 3.0 for Web 4.0; smartphones; tablets; smart watches; phablets (i.e., phones with a larger screen, hybrid phone and tablet), the benefit it will confer on the quality of learning should be borne in mind.

The process of material development implies procedures (evaluation, adaptation, design, exploitation, production, and research) (Tomlinson, 2012) that, ideally, should establish a synergy in the process of developing materials aimed at language teaching. In the case of the development of digital materials for language learning (Masuhara, Mishan \& Tomlinson, 2017; Mishan \& Timmis, 2015), Masuhara and Tomlinson (2018) highlighted the work developed by 
Reinders and Pegrum (2016), a model composed of five categories, which aims to evaluate Mobile Assisted Language Learning (MALL) resources. In Masuhara and Tomlinson's (2018) point of view, this model could be adapted in the process of evaluating any type of digital material.

The proper use of digital materials and resources is therefore the key to the success of teaching and learning, as they are mediators between learners and the reality that is the subject of study (Navarro-Pablo, López-Gándara \& GarcíaJiménez, 2019). In fact, technology confers several benefits to Education in general, such as: it allows individual autonomy and collaborative interaction (e.g., Skype, Google Meet, SMS texting); collaborative and interactive writing (e.g., Google Docs, wikis); work collaboratively outside the classroom (e.g., eTwinning program) (Masuhara \& Tomlinson, 2018). How technology has been standardized in our environment will depend on personal and teaching contexts.

The challenges facing language teacher education under CALL, mentioned by Kessler and Hubbard (2017), should be the subject of in-depth analysis in teacher preparation. And, in the pandemic times we live in, COVID-19, these challenges need even more attentive and in-depth reflection and analysis, since teachers, with more or less digital skills, were forced to normalize their work of face-toface teaching to distance teachers (Organisation for Economic Co-operation and Development [OECD], 2020; United Nations Educational, Scientific and Culture Organization [UNESCO], 2020). Going back to the challenges of language teachers' education under CALL, the focus is on preparing teachers for change. Teachers should know and understand how to use new techniques in teaching, such as MALL (Kukulska-Hulme, Norris \& Donohue, 2015), and be aware and know how to direct new course settings (e.g., VLE; MOOC); receive preparation for the creation of interactive materials that are as authentic as possible, as well as language experiences and environments; receive, for example, preparation at Gamificación level (Moura, 2018, 2019); to work on iCALL (intelligent CALL) field tools (e.g., natural language processing - NLP) (Meurers, 2012); to prepare teachers for the social future, in which social networks offer a multitude of benefits for language teaching, but require new skills and attitudes, since many activities developed in social networks distance themselves from conventional teacher focus; and prepare teachers for the challenges of "standardization", a "stage when a pedagogical technology such as a textbook or pen has become in effect invisible, so seamlessly is it employed in our everyday practice in the service of language learning" (Bax, 2011, p. 1), but it is imperious to apply what Bax (2013) designated Needs Audit, to determine the desirability, need and adoption of specific aspects in the field of language teaching and teacher preparation. Therefore, "Needs Audit should focus on learning and not on learners" (Bax, 2013, p. 43).

The integration of digital information and communication technologies in the educational context has suggested changes in the attitude of both teachers and students, with the purpose of enhancing pedagogical actions to be led by both. Introducing technologies in the educational field implies bearing in mind two 
major groups of constraints: external and internal (Costa, 2012). Internal include teachers, instructors, beliefs, views on technology and views on teaching, learning and knowledge (Wünsch, 2013). In the external, perhaps more determinant than the internal ones, there is lack of time, inadequate preparation, lack of knowledge, lack of will, lack of resources, insufficient technical support, inadequate use, age (Uzunboylu \& Tuncay, 2010), or even lack of experience (Mahdi \& Al-Dera, 2013). Kessler and Hubbard (2017) added that "teachers are often overwhelmed by such potential tools. ... Or they may simply be uncertain how to implement new technologies in their classroom" (p. 284).

In addition to personal factors, one of the main issues of integrating ICT into an educational context is directly related to the knowledge and skills teachers have about the ways in which ICT is integrated and explored in the specific teaching and learning contexts, and in many cases with the lack of infrastructure (lack of computers and internet) (Neto \& Cerny, 2018). From the reluctance that still persists (on teachers' behalf) regarding the integration of ICT in an educational context, or even mistrust, it is inferred that training should be structured in order to make teachers recognize the benefits that the use of a computer can bring to learning and become aware of its importance as an intellectual work tool, as a condition of changing their practices (Rodrigues, Oliveira, Cassundé, Morgado \& Barbosa, 2018).

Kessler and Hubbard (2017, p. 282) reported that some studies indicate that, in teacher education for CALL, there is inadequate breadth; lack of contextualization; failure to implement the knowledge acquired in a given training; and a dependency on informal preparation.

Research in the field of language teacher education has been set aside for the benefit of learning, although about two decades ago this scenario began to subvert itself (Van den Branden, 2016). This is a non-naturally simple job that requires a (re)construction of teaching training practices (Missel, 2018; Moreira \& Monteiro, 2015; Wünsch, 2013).

Language teachers need technology-level preparation, and put into practice such knowledge in teaching contexts or in similar scenarios; contextualized tasks that simulate real teaching situations; support at the level of training, and even institutional; collaborative and reflective hands-on opportunities (Aşık \& Gonen, 2019). Kessler and Hubbard (2017) suggested that the training of the language teacher for CALL should focus on:

- Adequate assessment of learning (computer-assisted language testing CALT). The two fields closer to classroom evaluation are: automated writing evaluation (AWE) and automated speaking evaluation (ASE). The future flows in the direction of computational feedback and automated evaluation.

- Feedback.

- The observation and monitoring of learners' behavior, as well as their progress which digital media provide, are highly beneficial for teacher training. 
- Social networks (i.e., the preparation of language teachers should be on par with the most emerging social networks, adopted for educational purposes, which have had a direct impact on communication and learning).

Within the Portuguese context, teacher training practices for the use of initial and continuous ICT are still very attached to traditional practices and models of teacher preparation in general (Costa, 2013). In a world dominated by technological advances, it is peremptory for teachers to develop their digital/technological competence, in order to gain access, analyze and synthesize, reflect and validate and, finally, transmit knowledge, using technologies in general and ICT in particular (Bastos, 2014). Digital skills include a set of knowledge, skills, attitudes (including skills, strategies, values and awareness) that are required when using ICT and digital media to perform tasks; solve problems; communicate; manage information; collaborate; create and share content; and to build an effective, efficient, adequate, critical, autonomous, flexible, ethical and reflective knowledge to work, for leisure time, for participation, for learning, for socialization, for consumption and for aggrandizement (Rodrigues et al., 2018; Silva \& Behar, 2019). For the training, Costa (2012) warned of the need to focus on peer collaboration and professional reality problems that allow teachers to reflect, question, learn, share, and develop new teaching methods with digital technologies. It is not enough to recognize the importance of technologies and be motivated for their use, but it is essential to have some technological knowledge, without which it will be difficult to make a reasoned and informed decision. It is peremptory, in this case, to try to know what technologies exist, what they do, what their degree of learning difficulties are, and what technical requirements are necessary for them to be used by students.

\section{Methodology}

As mentioned in the Introduction of this presentation, this research began by delimiting the problem which should bring knowledge to the scientific community (Cubo, Martín \& Ramos, 2011); and, subsequently, defining the specific objectives. Given the delimited problem, hypotheses were established.

The research methodology was selected according to the most appropriate strategy for assessing hypotheses; the sample, according to the methodology; and the assessment instruments according to the hypotheses and subjects. This presentation is then the result of a mixed investigation. The chosen model was follow-up explanations (Creswell, 2003). The quantitative and qualitative phases, which will from now on be designated as F1 and F2, respectively, were carried out spatially. Firstly, F1 and, secondly, F2. Data was collected and analysed quantitatively (F1); next qualitative data was collected and analysed (F2); and, ultimately, the entire analysis was interpreted (Dal-Farra \& Lopes, 2013).

The research instruments adopted were questionnaire (F1) and semi-structured interviews (F2). In F1, IBM SPSS Statistics 22.0 software was used to verify the 
internal consistency of the questionnaire, but also to accomplish descriptive and inferential analysis. In F2, NVivo 12 software was used for content analysis.

Methodological procedures will now be presented. First, we present the procedures of F1 and, later, of F2.

\section{Procedures}

\subsection{Quantitative phase (F1)}

To reach the sample (F1), several stages were considered: 1) population identification; 2) sample selection method; and 3) sample dimensions.

We started with the population, whose characteristics should be common to each other. This population had in common the fact that they had taught and/or still teach PNNL (PSL/PFL/PHL) in an endolingual context and/or in an exolingual context.

The sample selection method adopted was the non-probabilistic sampling method, more specifically the convenience sampling. Therefore, we first contacted Camões, I.P. an institution under the Portuguese Ministry of Affairs that aims to promote Portuguese worldwide. Teaching Portuguese Language and Culture is one of the areas Camões, I.P. relates to.

The questionnaire, validated by five experts in the area and later formulated in Google Forms (Internet-based survey), was sent by email to 375 institutions associated with Camões, I. P., all of them related to the teaching of Portuguese Language and Culture, in order to obtain answers from teachers. Over a period of 75 days at the end of 2016, 101 valid responses were obtained. The Questionnaire was organized in four dimensions (first Sociodemographic Data; second, Teacher Training; third, Digital Educational Resources; and fourth, Language Teaching Methods). For this presentation, the variables under analysis were obtained from the 1st, 2nd, and 3rd Dimensions, consisting of a total of 8 , 20 and 10 questions, respectively. Dichotomic and Likert scales (5 categories) were applied, although in the 1st Dimension there were also 2 sub-questions with gaps to fill in. Reliability was obtained through internal consistency, and the coefficient $\alpha$ was applied. The values obtained for each dimension were: $\alpha=$ .225 (Dimension 1); $\alpha=.847$ (Dimension 2); and $\alpha=.889$ (Dimension 3).

\subsection{Qualitative phase (F2)}

The qualitative sample (F2) resulted from a population that derived from the quantitative sample (F1). The F1 subjects, who made themselves available to conduct remote interviews in F2, provided their contacts (e-mails). From a total of 40 contacts established, there was a return of 20 responses (Table 1). The interview, semi-structured, as mentioned, was carried out remotely, in a time frame that varied between 20' and 30'; through Skype, Hangouts, Gmail chat and phone, depending on respondents' preference. 
Table 1: Distribution of Quantitative and Qualitative Samples

\begin{tabular}{|l|c|c|c|c|}
\hline \multirow{2}{*}{ Age } & \multicolumn{2}{|c|}{ S1 } & \multicolumn{2}{c|}{ S2 } \\
\cline { 2 - 5 } & Frequency & Percent & Frequency & Percent \\
\hline $20-29$ & 8 & 7.9 & & \\
\hline $30-39$ & 53 & 52.5 & 13 & 65 \\
\hline $40-50$ & 25 & 24.8 & 5 & 25 \\
\hline$>51$ & 15 & 14.9 & 2 & 10 \\
\hline Total & 101 & 100 & 20 & 100 \\
\hline Note. S1=Quantitative Sample; S2=Qualitative Sample \\
\hline \multicolumn{5}{l}{} \\
\hline
\end{tabular}

\section{Results}

The investigation results will be presented in the following order: first (5.1.) quantitative results (F1), including descriptive data (5.1.1.) and inferential data (5.1.2); second, (5.2.) qualitative results (F2), including (5.2.1) results from content analysis; and finally, (5.3), the discussion of the results of the investigation.

\subsection{Quantitative results}

\subsubsection{Descriptive analysis}

In the descriptive analysis, five questions of the questionnaire were considered: one of the Sociodemographic Dimension (Q1. Age), the results of which are available in Table 2 and Table 3; one of the Teacher Training Dimension (Q2. Have you attended any continuing training of PNNL?) and three of the Digital Educational Resources Dimension (Q3. For PNNL Teaching-Learning do you usually use Web 2.0 tools?; Q4. Considers that teachers, generally, do not use Web 2.0 tools due to lack of experience; and Q5. Considers that teachers, generally, do not use Web 2.0 tools due to lack of time), the results of which are available in Table 4 .

Table 2: Frequency distribution of the variable "Teacher's Age"

\begin{tabular}{|l|c|c|c|}
\hline \multicolumn{2}{|l|}{ Age } & Frequency & Percent \\
\hline \multirow{4}{*}{ Valid } & $20-29$ (age) & 8 & 7.9 \\
\cline { 2 - 4 } & $30-39$ (age) & 53 & 52.5 \\
\cline { 2 - 4 } & $40-50$ (age) & 25 & 24.8 \\
\cline { 2 - 4 } & $>51$ (age) & 15 & 14.9 \\
\hline Total & 101 & 100.0 \\
\hline
\end{tabular}

Table 3: Trend measures of the variable "Teacher's Age"

\begin{tabular}{|c|c|c|c|c|}
\hline \multicolumn{5}{|c|}{ Descriptive Statistics } \\
\hline \multirow{2}{*}{ Age } & $N$ & $M$ & $S D$ & Variance \\
\cline { 2 - 5 } & 101 & 2.47 & .843 & .711 \\
\hline Valid N (listwise) & 101 & & & \\
\hline
\end{tabular}


Table 4: Distribution of frequencies and trend measures of the variables "Continuous Training", "Use of Technologies", "Experience" and "Time".

\begin{tabular}{|c|c|c|c|c|c|c|c|c|}
\hline \multirow[b]{2}{*}{ Question } & \multirow{2}{*}{$\begin{array}{c}\text { Nominal scale (Frequency) } \\
\mathrm{Y} / \mathrm{N}\end{array}$} & \multicolumn{5}{|c|}{ Likert scale (Frequency) } & \multirow[b]{2}{*}{$M$} & \multirow[b]{2}{*}{ SD } \\
\hline & & TD & $\mathrm{D}$ & A & TA & DK & & \\
\hline $\mathrm{Q}^{\mathrm{a}}$ & $42 / 59$ & & & & & & .42 & .495 \\
\hline $\mathrm{Q}^{\mathrm{b}}$ & $66 / 35$ & & & & & & .65 & .478 \\
\hline $\mathrm{Q}^{\mathrm{c}}$ & & 6 & 11 & 28 & 3 & 6 & 3.00 & .825 \\
\hline $\mathrm{Q}^{\mathrm{d}}$ & & 2 & 45 & 37 & 11 & 6 & 2.74 & .902 \\
\hline
\end{tabular}

Note. $\mathrm{Y}=y e s ; \mathrm{N}=$ no; $\mathrm{TD}=$ totally disagree; $\mathrm{D}=$ disagree; $\mathrm{A}=$ agree; $\mathrm{TA}=$ totally agree; $\mathrm{DK}=$ doesn't know.

a Have you attended any continuing training of PNNL? ${ }^{b}$ For PNNL TeachingLearning do you usually use web 2.0 tools? ${ }^{\mathrm{c}}$ Considers that teachers, generally, do not use Web 2.0 tools due to lack of experience. ${ }^{d}$ Considers that teachers, generally, do not use Web 2.0 tools due to lack of time.

\subsubsection{Inferential analysis}

In the inferential analysis, the procedures applied for each work hypothesis were: first, a relationship was established between the study variables to decide which of the tests, parametric or non-parametric, would be adopted; second, the statistical test.

In the case of H1 (Table 5), as an association was made between two binary variables and as the assumptions for the use of the asymptotic chi square test were satisfied, this nonparametric test was the most appropriate.

Table 5: Cross-tabulation of variables "Use of Web 2.0 Tools in Pedagogical Practice" and "Frequency of Continuing Training for PNNL"

\begin{tabular}{|c|c|c|c|c|c|}
\hline \multicolumn{6}{|c|}{$\begin{array}{l}\text { For PNNL Teaching-Learning do you usually use Web } 2.0 \text { tools? Have you } \\
\text { attended any continuing training of PNNL? Crosstabulation }\end{array}$} \\
\hline \multirow{2}{*}{\multicolumn{3}{|c|}{ Variable }} & \multicolumn{3}{|c|}{$\begin{array}{l}\text { Have you attended any continuing training of } \\
\text { PSL/PFL/PHL? }\end{array}$} \\
\hline & & & $\begin{array}{ll}\text { No } \\
\end{array}$ & Yes & Total \\
\hline \multirow{6}{*}{$\begin{array}{l}\text { For PNNL } \\
\text { Teaching- } \\
\text { Learning do } \\
\text { you usually use } \\
\text { Web } 2.0 \text { tools? }\end{array}$} & \multirow[t]{2}{*}{ No } & Count & 24 & 11 & 35 \\
\hline & & $\%$ & $40.7 \%$ & $26.2 \%$ & $34.7 \%$ \\
\hline & \multirow[t]{2}{*}{ Yes } & Count & 35 & 31 & 66 \\
\hline & & $\%$ & $59.3 \%$ & $73.8 \%$ & $65.3 \%$ \\
\hline & \multirow[t]{2}{*}{ Total } & Count & 59 & 42 & 101 \\
\hline & & $\%$ & $100.0 \%$ & $100.0 \%$ & $100.0 \%$ \\
\hline
\end{tabular}

The result of the applied test is presented below (Table 6), and it was verified that $H_{0}$ was accepted, and therefore the work hypothesis was rejected.

Table 6: Exact Chi Square Results for H2.1

\begin{tabular}{|l|c|c|c|}
\hline \multirow{2}{*}{ Hypothesis } & \multicolumn{3}{|c|}{ Pearson Chi-Square } \\
\cline { 2 - 4 } & Value & df & Asymptotic Significance (2-sided) \\
\hline H1. & 2.274 a & 11 & .132 \\
\hline a0 cells $(0.0 \%)$ have expected count less than 5. The minimum expected count is 14.55. \\
\hline
\end{tabular}

In the case of $\mathrm{H} 2$, more specifically the $\mathrm{H} 2.1$ sub-hypothesis (Table 7), as an association between a binary variable and an ordinal categorical variable was 
performed, we chose to consider the nonparametric chi square for trend test to test whether the percentage of teachers using Web 2.0 tools increased or decreased according to the age group.

Table 7: Cross-tabulation of variables "Using Web Tools 2.0 in Pedagogical Practice" and "Age"

\begin{tabular}{|c|c|c|c|c|c|c|c|}
\hline \multicolumn{8}{|c|}{ For PNNL Teaching-Learning do you usually use Web 2.0 tools? Age Crosstabulation } \\
\hline \multirow{2}{*}{\multicolumn{3}{|c|}{ Variable }} & \multicolumn{5}{|c|}{ Age (years) } \\
\hline & & & $20-29$ & $30-39$ & $40-50$ & $>51$ & Total \\
\hline \multirow{6}{*}{$\begin{array}{l}\text { For PNNL Teaching- } \\
\text { Learning do you usually } \\
\text { use Web } 2.0 \text { tools? }\end{array}$} & \multirow[t]{2}{*}{ No } & Count & 3 & 19 & 10 & 3 & 35 \\
\hline & & $\%$ & $37.5 \%$ & $35.8 \%$ & $40.0 \%$ & $20.0 \%$ & $34.7 \%$ \\
\hline & \multirow[t]{2}{*}{ Yes } & Count & 5 & 34 & 15 & 12 & 66 \\
\hline & & $\%$ & $62.5 \%$ & $64.2 \%$ & $60.0 \%$ & $80.0 \%$ & $65.3 \%$ \\
\hline & \multirow[t]{2}{*}{ Total } & Count & 8 & 53 & 25 & 15 & 101 \\
\hline & & $\%$ & $100.0 \%$ & $100.0 \%$ & $100.0 \%$ & $100.0 \%$ & $100.0 \%$ \\
\hline
\end{tabular}

The results are presented below (Table 8), and it was verified that $H_{0}$ was accepted, and, therefore, the work hypothesis was rejected.

Table 8: Exact Chi Square Results for H2.1

\begin{tabular}{|l|l|c|c|}
\hline \multirow{2}{*}{ Hypothesis } & \multicolumn{3}{|c|}{ Pearson Chi-Square } \\
\cline { 2 - 4 } & Value & $\mathbf{d f}$ & $\begin{array}{c}\text { Asymptotic Significance (2- } \\
\text { sided) }\end{array}$ \\
\hline H2.1. & $1.800^{\mathrm{a}}$ & 33 & .615 \\
\hline a1 cells (12.,5\%) have expected count less than 5. The minimum expected count is 2.77. \\
\hline
\end{tabular}

Sub-hypotheses H2.2. (Table 9) and H2.3 (Table 10), as an association was made between two variables, one binary to another categorical with more than two unordered categories, and whereas one of the assumptions for the use of the asymptotic square chi test was not satisfied (at least $20 \%$ of the cells in the contingency table have an expected value of less than five), the exact nonparametric chi square was considered to be the most appropriate.

Table 9: Cross-tabulation of variables "Using Web Tools 2.0 in Pedagogical Practice" and "Lack of experience"

\begin{tabular}{|c|c|c|c|c|c|c|c|c|}
\hline \multicolumn{9}{|c|}{$\begin{array}{l}\text { For PNNL Teaching-Learning do you usually use Web } 2.0 \text { tools? * } \\
\text { a) Lack of experience Crosstabulation }\end{array}$} \\
\hline \multirow{2}{*}{\multicolumn{3}{|c|}{ Variable }} & \multicolumn{6}{|c|}{ Lack of experience } \\
\hline & & & $\mathrm{TD}$ & $\mathrm{D}$ & A & TA & DK & Total \\
\hline \multirow{6}{*}{$\begin{array}{l}\text { For PNNL } \\
\text { Teaching- } \\
\text { Learning } \\
\text { do you } \\
\text { usually use } \\
\text { Web 2.0 } \\
\text { tools? }\end{array}$} & \multirow[t]{2}{*}{ No } & Count & 1 & 5 & 19 & 4 & 6 & 35 \\
\hline & & $\%$ & $50.0 \%$ & $23.8 \%$ & $31.7 \%$ & $36.4 \%$ & $85.7 \%$ & $34.7 \%$ \\
\hline & \multirow[t]{2}{*}{ Yes } & Count & 1 & 16 & 41 & 7 & 1 & 66 \\
\hline & & $\%$ & $50.0 \%$ & $76.2 \%$ & $68.3 \%$ & $63.6 \%$ & $14.3 \%$ & $65.3 \%$ \\
\hline & \multirow[t]{2}{*}{ Total } & Count & 2 & 21 & 60 & 11 & 7 & 101 \\
\hline & & $\%$ & $100.0 \%$ & $100.0 \%$ & $100.0 \%$ & $100.0 \%$ & $100.0 \%$ & $100.0 \%$ \\
\hline
\end{tabular}


Table 10: Cross-tabulation of variables "Using Web Tools 2.0 in Pedagogical Practice" and "Time"

\begin{tabular}{|c|c|c|c|c|c|c|c|c|}
\hline \multicolumn{9}{|c|}{$\begin{array}{l}\text { For PNNL Teaching-Learning do you usually use Web } 2.0 \text { tools? } \\
\qquad \text { c) Lack of time. Crosstabulation }\end{array}$} \\
\hline \multirow{2}{*}{\multicolumn{3}{|c|}{ Variable }} & \multicolumn{6}{|c|}{ c) Lack of time. } \\
\hline & & & $\mathrm{TD}$ & $\mathrm{D}$ & A & TA & DK & Total \\
\hline \multirow{6}{*}{$\begin{array}{l}\text { For PNNL } \\
\text { Teaching- } \\
\text { Learning } \\
\text { do you } \\
\text { usually } \\
\text { use Web } \\
2.0 \text { tools? }\end{array}$} & \multirow[t]{2}{*}{ No } & Count & 1 & 15 & 12 & 3 & 4 & 35 \\
\hline & & $\%$ & $2.9 \%$ & $42.9 \%$ & $34.3 \%$ & $8.6 \%$ & $11.4 \%$ & $100.0 \%$ \\
\hline & \multirow[t]{2}{*}{ Yes } & Count & 1 & 30 & 25 & 8 & 2 & 66 \\
\hline & & $\%$ & $1.5 \%$ & $45.5 \%$ & $37.9 \%$ & $12.1 \%$ & $3.0 \%$ & $100.0 \%$ \\
\hline & \multirow[t]{2}{*}{ Total } & \begin{tabular}{|l|} 
Count \\
\end{tabular} & 2 & 45 & 37 & 11 & 6 & 101 \\
\hline & & $\%$ & $2.0 \%$ & $44.6 \%$ & $36.6 \%$ & $10.9 \%$ & $5.9 \%$ & $100.0 \%$ \\
\hline
\end{tabular}

The results of the tests applied in the analysis of the H2.2 and H2.3 subhypotheses are presented below. It was verified that, regarding the subhypothesis $\mathrm{H} 2.2, \mathrm{H}_{0}$ was rejected, and therefore the work hypothesis was accepted; and as for the $\mathrm{H} 2.3$ sub-hypothesis, $H_{0}$ was accepted, and therefore the work hypothesis was rejected (Table 11).

Table 11: Exact Chi Square Results for H2.2 e H2.3 Hypotheses

\begin{tabular}{|l|c|c|c|c|}
\hline \multirow{2}{*}{ Hypotheses } & \multicolumn{4}{|c|}{ Pearson Chi-Square } \\
\cline { 2 - 5 } & Value & $\mathbf{d f}$ & $\begin{array}{c}\text { Asymptotic } \\
\text { Significance (2-sided) }\end{array}$ & Exact Sig. (2-sided) \\
\hline H2.2. & $9.609^{\mathrm{a}}$ & 44 & .048 & .040 \\
\hline H2.3. & $3,303^{\mathrm{b}}$ & 44 & .408 & .524 \\
\hline $\begin{array}{l}\text { a5 cells (50.0\%) have expected count less than 5. The minimum expected count is .69. } \\
\text { b5 cells (50.0\%) have expected count less than 5. The minimum expected count is .69. }\end{array}$ \\
\hline
\end{tabular}

\subsection{Qualitative results}

\subsubsection{Content analysis}

Regarding the results obtained in F1, and to better understand them, we wanted to assess what kind of difficulties teachers experience in pedagogical practice, particularly in terms of ICT integration. Thus, out of a total of 6 questions formulated for the interview, we analyzed the question What difficulties do you feel/felt while teaching PNNL (PSL/PFL/PHL)?

The category Difficulties in ICT Use was created, and 7 subcategories were identified (Figure 1). 


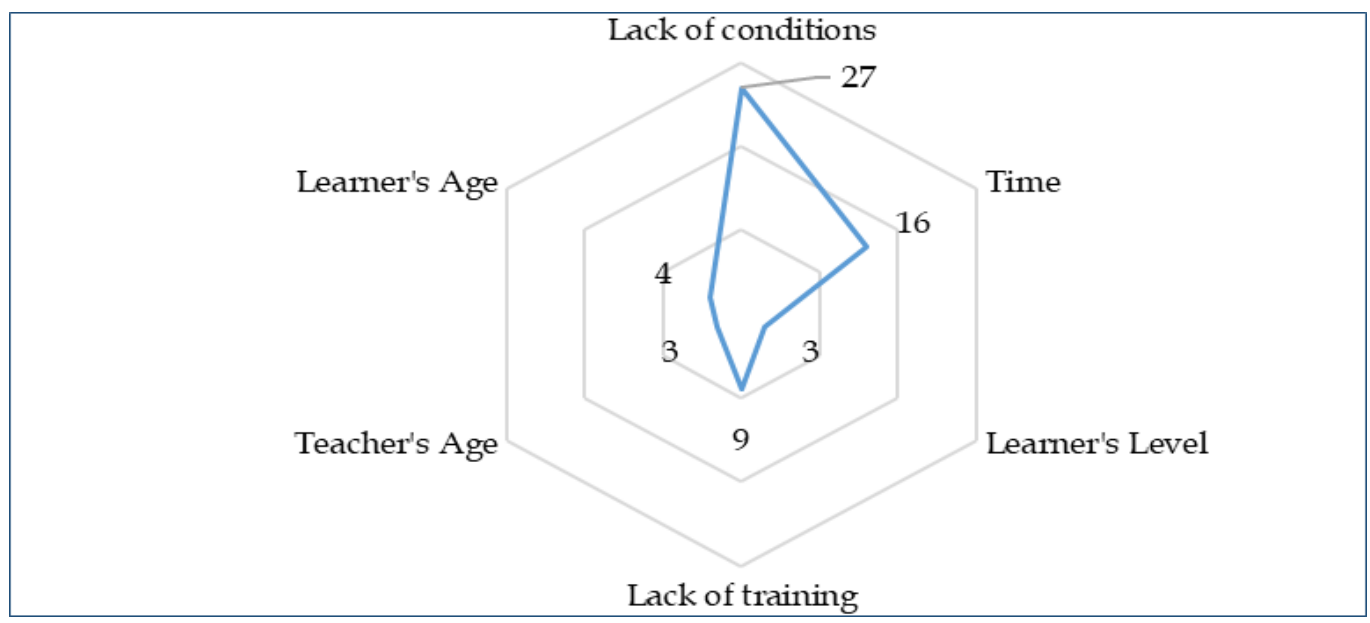

Figure 1: Distribution of segments of Difficulties in ICT Use category

Regarding the subcategory Lack of Conditions, Classrooms [Salas] (Figure 2) is the word that most often arises, relating, roughly, to the lack of conditions of the rooms, as evidenced in the segments that are subsequently available. To ensure the anonymity of the interviewed teachers, we have assigned them fictitious names.

"I use ICT when I can and when possible in the classroom. I don't always have all the materials I need to be able to do that, that is, I don't have internet in all classrooms and sometimes I don't even have a computer." (teacher "Vasco", L. 28-31).

"Because, okay, I do not know how it is like at other universities, but in mine the rooms are basically not equipped." (teacher "Clarisse", L. 3740).

"there is always that daily problem of: today there is one that does not work; the keyboard was broken; or any other problem." (teacher "Vitória", L. 64-66).

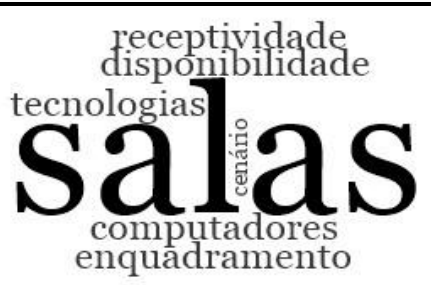

Figure 2: Most accounted terms in the Lack of Conditions subcategory.

As for the subcategory Time, the teachers' lack of time turned out to be another restrictive element in the use of digital tools in teaching practice. Teacher "Amelia" alluded to the time that usually needs to be spent, which for her is a lot, to be able to complete a certain activity that she had thought of:

"I really wasted so much time, so much time to insert an image, a simple thing... they had to identify parts of the house and, okay, I think this is one of the flaws." (L. 121-123). 
Teacher "Ema", despite the lack of time she admitted to not having, acknowledged, however, that many of the existing digital tools serve precisely to fight the lack of time:

" I do lack time to research properly because many of these tools are exactly to fight against lack of time." (L. 149-151).

In the analysis of the segments it was noticed that another element that conditions the process of using ICT, in addition to Time, is the Lack of training, as teacher "Emilia" admitted:

"I confess, in addition to the scarce or no training offer... at least that I know about in this area, is time." (L. 49-51).

The following segments also indicate the Lack of Training as an inhibitor in the use of digital tools in teaching practice:

"So, we honestly did not have the training to use them. We often have to figure it out, don't we?" (teacher "Inês", L. 77-78).

Another teacher said:

"There is also a problem of lack of training in this regard." (teacher "Cláudia", L. 38).

The fact that teachers admitted they have little and/or rudimentary knowledge in terms of digital tools for use in teaching practice, is another element that supports the subcategory Lack of training, as teacher "Rita" revealed:

"My computer skills are restricted to the basic computer user skills, even

Word and Excel." (L. 89-91).

Teacher "Ana" said:

"I have some difficulties using the computer at a higher level... Let's say I'm a simple user. I am not an expert in any aspect." (L. 39-42).

However, as teacher "José" said, although the lack of preparation is clearly sensed, the relevance of ICT in PNNL teaching practice is recognized:

"In fact, I feel that people of my generation are not as well prepared as they should be, and I acknowledge that, in the little that I see, there is a lot of potential in information technologies and technological means, to teach PL or PNNL." (L. 100-104).

In the Teacher's Age subcategory, the age of the teacher would be referred to as an aspect that would serve as a conditioning factor in the use of ICT:

"I'm still from the time of "Portuguese Without Borders", a prehistory.

I am still from the prehistoric age." (teacher "José", L. 80-81).

The same was expressed by teacher "Raquel":

"I think it is a common feeling among colleagues in my age group, the biggest problem is the scant or insufficient mastery of these same technologies by digital migrants." (L. 25-27). 
Teacher "João" also shared a similar opinion:

"I'm almost 40 years old, so I'm already one of those Word whizzes, I work with Word and I like it, I'm already specialized in it. I consider them useful but I rarely integrate them. " (L. 171-175).

In the Learner's Age subcategory, the most advanced age of the learner would also be referred to as being a condition, especially when the teacher is faced with groups whose age range is not homogeneous, as teacher "Cláudia" said: " you must be patient, because I had students up to 83 years of age. He didn't even have an e-mail, and we had to e-mail them so we could interact, I mean... and sometimes also depending on the class, depending on the group, there is no time to stop sometimes with some people, or help them to be able to pursue". (L. 142-146).

On the other hand, if the group of learners is made up of an adult audience, it was argued that the use of ICT would not make as much sense, since this public would not be receptive to the adoption of different teaching strategies, as pointed out by teacher "Nuno":

"At this moment, as it is an adult audience, it does not make much sense, even on their behalf I do not notice great difficulty, in learning in a more traditional way as it has been, I would say. On the other hand, I don't notice that they really want to do different things." (L. 62-66).

The Learner's Level subcategory, associated with the level of language proficiency, was referred to as another inhibiting aspect in the use of ICT in teaching practice. In other words, if the learner's level of proficiency were more advanced, it would not be justified to resort to its use, as teacher "Inês" said:

"I have used it. It's not systematic, because they're actually students of a higher level, they're students who need other approaches." (L. 51-52).

Teacher "Teresa" also shared an identical opinion:

"As I normally teach C-levels, I have little recourse to this type of things, because this type of things is more for A, B1 and even B2. If it's a strong B2, it starts to fail a lot, in terms of manuals, materials." (L. 2427).

\subsection{Discussion of results}

The results of $\mathbf{H 1}$. hypothesis revealed that teachers no longer use digital educational resources, regardless of the ongoing training they have attended, assuming that these trainings will not be contemplating a development of technological and pedagogical-didactic knowledge and skills (Costa, 2012; Kurek, 2015; Nakashima \& Piconez, 2016; Santos \& Costa, 2013). For all this, it appears that, as suggested by several authors (Costa, 2013; Felizardo \& Costa, 2016), training practices for the use of ICT remain very attached to traditional teacher preparation practices and models, at least as far as Portugal is concerned.

In addition to the attempt to portray the training scenario (initial and continuous) for the teaching of PNNL, the reason why the use of ICT among 
teachers was still extremely limited remained unclear. Thus, we tried to understand whether factors such as age (H2.1.), teacher experience (H2.2.) and time (H2.3.) contributed to the low use of ICT in the exercise of these teachers.

With regard to the sub-hypothesis H2.1., which was rejected, the results suggested that the age factor would not justify the low use and integration of ICT in PNNL teaching, coinciding with several studies (Inan \& Lowther, 2010; Van der Kaay \& Young, 2012). However, these results contrast with other studies (Mahdi \& Al-Dera, 2013; Uzunboylu \& Tuncay, 2010), as well as with the results of content analysis, more specifically with the subcategory Teacher's Age, deriving from the subcategory Difficulties in the use of ICT. In other words, the interviewed teachers linked the age factor to two essential aspects: trust and competence. This ambivalence leads us to a gap in terms of age, as a motivating or repressive factor for the use of ICT. In the analysis of the results of the subhypothesis H2.2., which was accepted, it was found that the teacher's experience emerges as an element that conditions the use of technologies, as supported by a few authors (Baek, Jung \& Kim, 2008). However, typically, a more experienced teacher will also be an older teacher, thus constituting a countercensus if compared with the result of the previous sub-hypothesis (H2.1.). As for age, there are two pendulums, which, in part, may justify these paradoxical data (Russell, Bebell, O'Dwyer \& Duffany, 2003): the degree of confidence and beliefs. The same authors, in the study they carried out, Use, Support, and Effect of Instructional Technology (USEIT), found that teachers who had five or fewer years of experience were significantly more confident than teachers who taught between 6 and 15 years or more. That is, younger teachers are more confident in the use of technologies than those who have been in the profession for 6 years or more. However, the same study indicates that younger teachers tend to believe that technologies have a negative impact on students' learning (e.g., makes them lazier; decreases their ability to research; compromises orthographic quality), contrary to what happens with more experienced teachers. Thus, the results obtained in both subhypothesis may be related to the teacher's confidence in the use of technologies (Buabeng-Andoh, 2012; Peralta \& Costa, 2007; Kamalodeen, Figaro-Henry, Ramsawak-Jodha \& Dedovets, 2017), on one hand, and with the teacher's attitudes (Hew \& Brush, 2007; Keengwe, Onchwari \& Wachira, 2008), on the other. As for the time factor, it was interesting to verify that the subhypothesis H2.3. would be rejected. But there are studies that indicate the opposite. In other words, lack of time is one of the variables that conditions the use of ICT in teaching practice (Harrell \& Bynum, 2018; Kamalodeen et al., 2017).

Also, in the course of content analysis (F2), in particular in the analysis of the subcategory Time, deriving from the subcategory Difficulties in the use of ICT, some of the teachers interviewed mentioned the non-use of ICT was due to lack of time (Harrell \& Bynum, 2018). But, going back to the result of this hypothesis, it may well be understood that it would be related to the fact that technologies can be seen as a facilitating element in time management (Ramos, Teodoro \& Ferreira, 2011; Mustafina, 2016), an opinion shared by one of the interviewed teachers $(\mathrm{F} 2)$. 
But for this to happen, interoperability, digital literacy and infrastructure creation (Muslem, Yusuf \& Juliana, 2018), this last aspect being pointed out in content analysis as an impediment factor in the use of ICT, must be implemented. In other words, in the analysis of the sub subcategory Lack of conditions, it was said that the classrooms where teachers taught did not meet the conditions for the use of ICT in teaching practice, due to limited or conditioned access to the Internet; lack of computers; obsolete computers; or even the lack of audiovisuals. As for digital literacy, closely related to training, which should cross both technological and pedagogical skills (Mahdi \& Al-Dera, 2013), and which would facilitate the time management process, it was found that, if this was inexistent it became another castrating element in the use and integration of ICT. The same was advocated by the teachers interviewed in F2, an opinion also shared in some studies (Bordbar, 2010; Drent \& Meelisen, 2008).

\section{Conclusion}

It was concluded that training (initial and continuous) is not preparing PNNL teachers for the integration of technologies in teaching, because there is no relationship whatsoever to the integration of technology in pedagogical practice. However, when analyzing the variables that condition the use of ICT (age, experience and time), a link to training was detected, because age and experience are associated with the confidence and attitudes of teachers, which can be acquired and changed, respectively, if there is good training, in particular one that establishes a real synergy between pedagogy and technology, especially now with the new normality, the result of the COVID-19 pandemic. On the other hand, if digital literacy were prepared, technologies would also be facilitating elements in time management. If the almost marginal importance given to digital literacy in Education were to be countered, the focus on the use and integration of mobile devices in teaching PNNL, for instance, would help to overcome the problem of infrastructure: that is, classrooms that are not properly equipped and prepared for the use of ICT. Frequently, the houses themselves are not equally equipped. In the training of PNNL teachers, the guiding principles of CALL, and even the proposed future challenges (e.g., MALL, VLE, interactive materials, iCALL, social networks), that in the pandemic times we live in are so current, should be a target of analysis and reflection, in particular the practices adopted in teaching, in the sense of teaching contexts, multiculturalism, multilingualism and globalization. But for the standardization of technology in teaching to be complete, the education of PNNL teachers must also audit learning needs.

\section{References}

Aşık, A., \& Gonen, S. (2019). A review of studies on CALL teacher education: Trends and issues. In G. Y. Ekşi, L. Guerra, D. Werbińska \& Y. Bayyurt (Eds.), Research trends in english language teacher education and english language teaching (pp. 343-363). Universidade de Évora.

Baek, Y. G., Jung, J., \& Kim, B. (2008). What makes teachers use of technology in the classroom? Exploring the factors affecting facilitation of technology with a korean sample. Computers and Education, 50(1), 224-234. doi:10.1016/j.compedu.2006.05.002 
Barbosa, M. P., \& Flores, C. M. (2011). Clíticos no português de herança de emigrantes bilingues de segunda geração. Textos seleccionados, XXVI Encontro da Associação Portuguesa de Linguística [Selected texts, XXVI Meeting of The Portuguese Linguistics Association] (pp. 81-98). Lisbon, Portugal: Associação Portuguesa de Linguística. Retrieved from http://repositorium.sdum.uminho.pt/bitstream/1822/14098/1/Barbosa_Flores _vers\%c3\%a3o\%20publicada.pdf

Bastos, M. S. (2014). A educação intercultural na formação contínua de professores de línguas [Intercultural education in the continuous training of language teachers] (Doctoral dissertation). Retrieved from https:/ / ria.ua.pt/handle/10773/12664

Bax, S. (2011). Normalisation revisited: The effective use of technology in language education. International Journal of Computer-Assisted Language Learning and Teaching, 1(2), 1-15. doi:10.4018/ijcallt.2011040101

Bax, S. (2013). Normalization revisited: The effective use of technology in language education. In B. Zou (Ed.), Explorations of language teaching and learning with computational assistance (pp. 35-49). Hershey, Pennsylvania: IGI Global.

Bizarro, R., Flores, C., \& Moreira, M. A. (2013). Reptos à investigação e ensino em português língua não materna. In R. Bizarro, M. A. Moreira \& C. Flores (Eds.), Português língua não materna: Investigação e ensino [Portuguese non-native language: Research and teaching] (pp. 17-22). Lisbon, Portugal: LIDEL - Edições Técnicas, Lda.

Bolívar, A., \& Ruano, R. B. (2013). Formação de professores. In R. Bizarro, M. Moreira, \& C. Flores (Eds.), Português língua não materna: Investigação e ensino [Portuguese nonnative language: Research and teaching] (pp. 100-110). Lisbon, Portugal: LIDEL Edições Técnicas, Lda.

Bordbar, F. (2010). English teachers' attitudes toward computer-assisted language learning. International Journal of Language Studies, 4, 179-206.

Branco, A., Mendes, A., Pereira, S., Henriques, P., Pellegrini, T., Meneido, H...., Bacelar, F. (n.d.). A lingua portuguesa na era digital [Portuguese language in the digital era]. Berlin, Germany: Springer.

Buabeng-Andoh, C. (2012). Factors influencing teachers' adoption and integration of information and communication technology into teaching: A review of the literature (EJ1084227). $\quad$ ERIC. Retrieved from https://files.eric.ed.gov/fulltext/EJ1084227.pdf

Carvalho, J. B. (2013). Didática do português língua não materna - língua segunda, língua estrangeira (entre a generalização e a especificação). In R. Bizarro, M. A. Moreira \& C. Flores (Eds.), Português língua não materna: Investigação e ensino [Portuguese non-native language: Research and teaching] (pp. 146-154). Lisbon: LIDEL - Edições Técnicas, Lda.

Castro, A. C. (2015). Materiais para o ensino do português como língua estrangeira: Uma proposta de aprendizagem baseada em tarefas [Materials for teaching portuguese as a foreign language: A task-based learning proposal]. (Doctoral dissertation). Retrieved from http://repositorioaberto.uab.pt/handle/10400.2/3281

Castro, A. C. (2017). Ensino de línguas baseado em tarefas - da teoria à prática [Task-based language teaching- from theory to practice]. Lisbon, Portugal: LIDEL - Edições Técnicas, Lda.

Costa, F. A. (2012). Repensar as TIC na educação: O professor como agente transformador [Rethinking ICT in education: Teacher as an agent of transformation]. [PowerPoint slides]. Slideshare. Retrieved from https://www.slideshare.net/digitalescola/501855-001-144 
Costa, F. A. (2013). O potencial transformador das TIC e a formação de professores e educadores. In M. E. Almeida, P. Dias, \& B. D. Silva (Eds.), Cenários de inovação para a educação na sociedade digital [Innovation scenarios for education in the digital society] (pp. 47-73). São Paulo, Brasil: Layola.

Creswell, J. W. (2003). Research design - qualitative, quantitative and mixed methods approaches. Thousand Oaks, California: Sage Publications.

Cubo, S., Martín, B., \& Ramos, J. (2011). Métodos de investigación y análisis de datos en ciencias sociales y de la salud [Research and analysis methods in social and health sciences]. Madrid, Spain; Pirámide.

Dal-Farra, R. A., \& Lopes, P. T. (2013). Métodos mistos de pesquisa em educação: Pressupostos teóricos [Mixed research methods in education: Theoretical assumptions]. Nuances: estudos sobre Educação, 24(3), 67-80. doi:10.14572/nuances.v24i3.2698

Drent, M., \& Meelisen, M. (2008). Which factors contribute or stimulate teacher educators to use ICT innovatively? Computers \& Education, 51(1), 187-199. doi:10.1016/j.compedu.2007.05.001

Felizardo, M. H., \& Costa, F. A. (2016). Perceção dos professores sobre a qualidade da formação na área das TIC. In N. Pedro, A. Pedro, J. F. Matos, J. Piedade, M. Fonte, G. Miranda, F. A. Costa, E. Cruz, J. Viana, N. Dorotea, N. Oliveira, \& S. Batista (Eds.), Atas do IV Congresso Internacional TIC e Educação 2016 - Tecnologias digitais e a escola do futuro [Proceedings of the IV International Congress ICT and Education 2016- Digital technologies and the school of the future] (pp. 117-133). Universidade de Lisboa.

Ferreira, J. C. (2014). Competência fonológica de alunos de português língua não-materna que frequentam o ensino regular português [Phonological competency of non-native language portuguese students attending regular portuguese schooling]. Lisbon, Portugal: Universidade Católica Portuguesa.

Flores, C. (2013). Português língua não materna: Discutindo conceitos de uma perspetiva linguística. In R. Bizarro, M. Moreira \& C. Flores (Eds.), Português língua não materna: Investigação e ensino [Portuguese non-native language: Research and teaching] (pp.35-46). Lisbon, Portugal: LIDEL - Edições Técnicas, Lda

Flores, C., \& Melo-Pfeifer, S. (2014). O conceito "língua de herança" na perspetiva da linguística e da didática de língua: Considerações pluridisciplinares em torno do perfil linguístico das crianças lusodescendentes na Alemanha [The concept of "heritage language" in a language linguistics and didatics perspective: Pluridisciplinary considerations regarding the language profile of portuguese descendent children in Germany]. Dominios Lingu@gem, 8, 16-45. http://repositorium.sdum.uminho.pt/handle/1822/30450

Goh, P. S. C., \& Abdul-Wahab, N. (2020). Paradigms to drive higher education 4.0 International Journal of Learning, Teaching and Educational Research, 19(1), 159-171. doi:10.26803/ijlter.19.1.9

Grosso, M. J. (n.d.). Língua não materna: Uma problemática conceptual [Non-native language: A conceptual problematic]. Revista ProFORMAR online, 22. Retrieved from http:// proformar.pt/revista/edicao_22/lnm_prob_conceptual.pdf

Grayley, M. V. (2014). A "internacionalização" do português e as novas relações de poder entre os países de língua portuguesa [The internationalization of portuguese and the new power relations between portuguese language countries]. (Doctoral dissertation). Retrieved from https://repositorioaberto.uab.pt/bitstream/10400.2/4772/6/TD_MonicaVillela _UA\%20Editada.pdf 
Harrell, S., \& Bynum, Y. (2018). Factors affecting technology integration in the classroom (EJ1194723). ERIC. Retrieved from https://files.eric.ed.gov/fulltext/EJ1194723.pdf

Hew, K. F., \& Brush, T. (2007). Integrating technology into K-12 teaching and learning: current knowledge gaps and recommendations for future research. Educational Technology Research and Development, 55, 223-253. doi:10.1007/s11423-006-9022-5

Inan, F. A., \& Lowther, D. L. (2010). Factors affecting technology integration in K-12 classrooms: a path model. Education Tech Research and Development, 58, 137-154. doi:10.1007/s11423-009-9132-y

Kamalodeen, V. J., Figaro-Henry, S., Ramsawak-Jodha, N., \& Dedovets, Z. (2017). The development of teacher ICT competence and confidence in using Web 2.0 tools in a STEM professional development initiative in Trinidad. Caribbean Teaching Scholar, 7, 25-46.

Keengwe, J., Onchwari, G. \& Wachira, P. (2008). Computer technology integration and student learning: Barriers and promise, Journal of Science Education and Technology, 17(6), 560- 565. doi:10.1007/s10956-008-9123-5

Kessler, G., \& Hubbard, P. (2017). Language teacher education and technology. In C. Chapelle, \& S. Sauro (Eds.), The handbook of technology and second language teaching and learning (pp. 278-291). Hoboken, New Jersey: Wiley \& Sons, Inc. doi:10.1002/9781118914069.ch19

Kukulska-Hulme, A., Norris, L., \& Donohue, J. (2015). Mobile pedagogy for english language teaching: A guide for teachers. London, England: British Council.

Kurek, M. (2015). Designing tasks for complex virtual learning environments. Bellaterra Journal of Teaching $\mathcal{E}$ Learning Language $\mathcal{E}$ Literature, 8(2), 13-32. doi: $10.5565 / \mathrm{rev} / \mathrm{jtl} 3.633$

Leiria, I. (2001). Léxico, aquisição e ensino do português europeu língua não materna [Lexicon, acquisition and teaching of european portuguese as a non-native language] (Doctoral dissertation). Retrieved from http://cvc.institutocamoes.pt/conhecer/biblioteca-digital-camoes/dissertacoes-e-teses.html

Mahdi, H. S., \& Al-Dera, A. S. (2013). The impact of teachers' age, gender and experience on the use of information and communication technology in EFL teaching. English Language Teaching, 6(6), 57-67. doi:10.5539/elt.v6n6p57

Masuhara, H., Mishan, F., \& Tomlinson, B. (Eds.) (2017). Practice and theory for materials development in L2 learning. Newcastle upon Tyne, England: Cambridge Scholars Publishing.

Masuhara, H., \& Tomlinson, B. (2018). The complete guide to the theory and practice of materials development for language learning. Hoboken, New Jersey: Wiley \& Sons, Inc.

Melo-Pfeifer, S., \& Araújo e Sá, M. H. (2013). Comunicação eletrónica na aula de português lingua estrangeira [Electronic communication in the portuguese as a heritage language class]. Lisbon, Portugal: LIDEL - Edições Técnicas, Lda.

Meurers, D. (2012). Natural language processing and language learning. In C. Chapelle (Ed.), Encyclopedia of applied linguistics. Hoboken, New Jersey: Wiley Blackwell.

Mishan, F., \& Timmis, I. (2015). Materials development for TESOL. Edinburgh University Press.

Missel, F. D. (2018). Reflexões sobre a disciplina isolada formação docente, subjetivação e tecnologias. In A. S. Neto \& R. Z. Cerny (Eds.), Narrativas autobiográficas de professores - (auto)formação e investigação em torno do currículo, formação docente e tecnologias digitais [Teachers' autobiographical narratives - (self)training and research about the curriculum, teacher training and digital technologies] (pp. 5869). São Paulo, Brasil: Pimenta Cultural. 
Moreira, J. A., \& Monteiro, A. (2015). Formação e ferramentas colaborativas para a docência na web social [Training and collaborative tools for teaching in the social web]. Revista Diálogo Educacional, 15(45), 379-394. doi:10.7213/dialogo.educ.15.045.DS01

Moura, A. (2018). Tecnologias móveis para o ensino e aprendizagem de português língua materna. In A. M. Lopes (Ed.) Atas das Jornadas de Lingua Portuguesa Investigação e Ensino [Proceedings of the Portuguese Language Sessions. Research and Teaching] (pp. 207-219). Cabo Verde: Edições Uni.

Moura, A. (2019). Uma estratégia de gamificação para envolver os alunos na aprendizagem de obras literárias. In P. Dias, D. Moreira, \& A. Quintas-Mendes (Eds.), Inovar para a qualidade na educação digital [Innovating for quality in digital education] (pp. 63-76). Lisbon, Portugal: Universidade Aberta.

Muslem, A., Yusuf, Y. Q., \& Juliana, R. (2018). Perceptions and barriers to ICT use among english teachers in Indonesia (EJ1170638). ERIC. Retrieved from https://files.eric.ed.gov/fulltext/EJ1170638.pdf

Mustafina, A. (2016). Teacher's attitudes toward technology integration in a Kazahstani secondary school (EJ1105117). ERIC. Retrieved from https:// files.eric.ed.gov/fulltext/EJ1105117.pdf

Nadais, I. (2018, April 30). A quarta língua mais falada do mundo não tem problemas de relacionamento [The fourth more spoken language in the world has no relationship problems]. Público. Retrieved from https://www.publico.pt/

Nakashima, R. H., \& Piconez, S. C. (2016). Technological pedagogical content knowledge (TPACK): Modelo explicativo da ação docente [Technological pedagogical content knowledge (TPACK): Explanatory model of teachers' action]. Reveduc Revista Eletrônica de Educação, 10(3), 231-250. doi:10.14244/198271991605

Navarro-Pablo, M., López-Gándara, Y., \& García-Jiménez, E. (2019). El uso de los recursos y materiales digitales dentro y fuera del aula bilingüe [The use of digital resources and materials in and outside the bilingual classroom]. Comunicar. doi:10.3916/C59-2019-08

Ndiaye, S. (2010). O processo comunicativo na aula do português, língua estrangeira, no Senegal: O multilinguismo como factor de construção discursiva em contexto pedagógico [The communicative process in the foreign language portuguese class in Senegal: Multilingualism as a discourse construction factor in a pedagogical context]. (Doctoral dissertation). Retrieved from http://repositorium.sdum.uminho.pt/handle/1822/12483

Neto, A. S. \& Cerny, R. Z. (2018). Tecnologias digitais, currículo e formação docente: Narrativas de docentes como processo de autoformação. In A. S. Neto \& R. Z. Cerny (Eds.), Narrativas autobiográficas de professores - (auto)formação e investigação em torno do currículo, formação docente e tecnologias digitais [Teachers' autobiographical narratives- (self)training and research about the curriculum, teacher training and digital technologies](pp. 10-43). São Paulo, Brasil: Pimenta Cultural.

Organisation for Economic Co-operation and Development (2020). Education responses to covid-19: Embracing digital learning and online collaboration. Retrieved from https://oecd.dam-broadcast.com/pm_7379_120_120544-8ksud7oaj2.pdf

Osório, P., \& Meyer, R. M. (Eds.), (2008). Português língua segunda e língua estrangeira: $D a(s)$ teoria(s) à(s) prática(s) [Portuguese second language and foreign language: From theory to practice]. Lisbon, Portugal: LIDEL - Edições Técnicas, Lda.

Peralta, H., \& Costa, F. A. (2007). Teachers' competence and confidence regarding the use of ICT. SÍSIFO - Educational Science Journal, (3), 75-84. 
Ramos, J. L., Teodoro, V. D., \& Ferreira, F. M. (2011). Recursos educativos digitais: Reflexões sobre a prática [Digital educational resources: Reflexions concerning practice]. Cadernos SACAUSEF, 11-34. Retrieved from https://dspace.uevora.pt/rdpc/bitstream/10174/5051/1/1330429397_Sacausef 7_11_35_RED_reflexoes_pratica.pdf

Reinders, H., \& Pegrum, M. (2016). Supporting Language Learning in the Move. In B. Tomlinson (Ed.), SLA Research and Materials Development for Language Learning (pp. 221-233). London, England: Routledge.

Reinders, H., \& White, C. (2010). The theory and practice of technology in materials development and task design. In N. Harwood (Ed.), English language teaching materials: Theory and practice (pp. 58-80). Cambridge, England: Cambridge University Press.

Rodrigues, N. F., Oliveira, M. V., Cassundé, F. R., Morgado, L., \& Barbosa, M. C. (2018). Os professores, as tecnologias e as competências digitais: Proposições teóricas. In A. Pedro, J. Piedade, J. Matos, N. Dorotea, \& N. Pedro (Eds.), Technology enhanced learning - Livro de Atas do V Congresso Internacional TIC e Educação [Technology enhanced learning - Book of Proceedings of the $\mathrm{V}$ International Congress ICT and Education]. Instituto de Educação da Universidade de Lisboa. Retrieved from http://ticeduca.ie.ul.pt/atas/atas_te_2018.pdf

Russell, M., Bebell, D., O'Dwyer, L. \& O'Connor, K. (2003). Examining teacher technology use. Journal of Teacher Education, 54, 297-310. doi:10.1177/0022487103255985

Santos, S. R., \& Costa, P. M. (2013). Sobre a didática e as didáticas específicas: O que está em questão na formação docente? [Didactics and specific didactics: What is at stake in teacher training?] Revista de Educação, Ciências e Matemática, 3, 15-30.

Silva, A. A., \& Marçalo, M. J. (2015). O português língua estrangeira: Adaptação de materiais à web 2.0. In P. Osório, \& F. d. Bertinetti (Eds.) Teorias e usos linguísticos - aplicação ao português língua não materna [Theories and linguistic uses - applying it to portuguese non-native language] (pp. 212-245). Lisbon, Portugal: LIDEL Edições Técnicas, Lda.

Silva, K. K., \& Behar, P. A. (2019). Competências digitais na educação: Uma discussão acerca do conceito [Digital competencies in education: A discussion about the concept]. EDUR - Educação em Revista, 35, 1-32. doi:10.1590/0102-4698209940

Sjöberg, J., \& Lilja, P. (2019). University Teachers' Ambivalence about Digital Transformation of Higher Education. International Journal of Learning Teaching and Educational Research, 18(3), 133-149. https:/ / doi.org/10.26803/ijlter.18.13.7

Tavares, A. (2008). Ensino/aprendizagem do português como lingua estrangeira - manuais de iniciação [Teaching/learning portuguese as a foreign language - beginners manuals]. Lisbon, Portugal: LIDEL - Edições Técnicas, Lda.

Tomlinson, B. (2012). Materials development for language learning and teaching. Language Teaching, 45(2) 143-179. doi:10.1017/S0261444811000528

United Nations Educational, Scientific and Culture Organization. (2020). Fighting COVID-19 through digital innovation and transformation. Retrieved from https://en.unesco.org/covid19/communicationinformationresponse/digitalinn ovation

Uzunboylu, H., \& Tuncay, N. (2010). Divergence of digital world of teachers. Educational Technology \& Society, 13(1), 186-194.

Van den Branden, K. (2016). The role of teachers in task-based language education. Annual Review of Applied Linguistics, 36, 164-181. doi:10.1017/S0267190515000070 
Van der Kaay, C., \& Young, W. (2012). Age-related differences in technology usage among community college faculty. Community College Journal of Research and Practice, 36(8), 570-579.

Wünsch, L. (2013). Formação inicial de professores do ensino básico e secundário: Integração das tecnologias da informação e comunicação nos mestrados em ensino [Elementary school and highschool teachers' initial training: Integrating information and communication technologies in teaching masters] (Doctoral dissertation). Retrieved from https://repositorio.ul.pt/handle/10451/8616

Xambre, L., \& Morais, C. (2014). Formação de professores e desenvolvimento de recursos educativos digitais recorrendo a ferramentas da web 2.0. In G. Miranda, M. Monteiro \& P. Brás (Eds.), Aprendizagem online: Atas Digitais do III Congresso Internacional das TIC na Educação [Online learning: Digital Proceedings of the III International Congress on ICT in Education] (pp. 323-329). Instituto de Educação da Universidade de Lisboa. Retrieved from http://ticeduca2014.ie.ul.pt/downloads/AtasDigitais/Atas_Digitais_ticEDUC A2014.pdf 